Page 778-794. ISBN: 978-602-6 988-75-1

Web Jurnal Online: jurnal.unmuhjember.ac.id

By: Fauziyah

Authority of Settlement of Village Head Election Post Constitutional Court Decision

\title{
AUTHORITY OF SETTLEMENT OF VILLAGE HEAD ELECTION POST CONSTITUTIONAL COURT DECISION
}

\author{
Fauziyah \\ Faculty Of Law Jember Muhammadiyah University \\ Jl. Karimata 49 Jember, East Java, Indonesia \\ Email: fauziyah@unmuhjember.ac.id
}

\begin{abstract}
Disputes Election of village heads based on Law 6 of 2014 concerning Villages is resolved by the Regent as stipulated in Article 37 paragraph (6) states that the regent is obliged to settle disputes resulting from the election of a village head within 30 (thirty) days. Then further regulated at the district level, local regulations have been implemented that are adjusted to the local wisdom of each region. However, there is a Constitutional Court Decision Number 137 / PUU-XIII / 2015 and Number 56 / PUUXIV / 2016 which states that the central government does not have the authority to cancel provincial regulations, so it has logical consequences that there are regional regulations that contradict the above regulations. canceled so that the settlement of the dispute over the election of the village head was originally resolved by the Executive agency (regent) then it can turn to the Judiciary institution, namely in the State Administrative Court. This decision does not necessarily solve the problem of constitutionality of the authority to examine the product of regional law which incidentally is under the law. Juridical implications for the settlement of dispute over the results of the election after the Constitutional Court Decision Number 56 PUU /-XIV / 2016, the regent who made the Regional Regulation or Regulations of the regent, as well as the settlement authority. This shows the position of the regent as the executive has a dual role as a judicial institution. So the normative decision of the regent is not final, and can still be appealed to the District Court and the PTUN where the dispute occurred.
\end{abstract}

\section{Keywords: authority, annulment, Local regulation}


Proceeding ICOGISS 2019

Page 778-794. ISBN: 978-602-6 988-75-1

Web Jurnal Online: jurnal.unmuhjember.ac.id

By: Fauziyah

Authority of Settlement of Village Head Election Post Constitutional Court Decision

\section{Introduction}

One of the agendas in the Jokowi-JK Nawacita is to develop Indonesia from the periphery by strengthening the regions and villages. So with the issuance of Law 6 of 2014 concerning Villages of the State Gazette of the Republic of Indonesia Number 7 of 2014, Supplement to the State Gazette of the Republic of Indonesia Number 5495, is a benchmark that oversees village change to realize an innovative independent village so that a self governing Community is formed.

The number of villages to date has been around 73,000 (seventy three thousand) and around 8,000 (eight thousand) villages. Article 18 of the 1945 Constitution of the Republic of Indonesia which regulates the division of the Indonesian region into large and small areas where the village is regulated as a "small area" of large areas, the meaning of the village must be understood as a legal community unit that has the rights and power in regulating and managing the interests of the community to achieve prosperity. The right to regulate and manage the interests of the community is what is called village autonomy.

Cancellation of local regulations is to implement the government's authority in relation to the local regulatory process. Law Number 23 Year 2014 About the Local Government Gazette Number 244 of 2014, Supplement to State Gazette No. 5587 of 2014, hereinafter referred to Local Government Law. Explicitly authorizes the Minister of the Interior and the Governor in steps to cancel the regional regulation and Regulation of the region as opposed to the higher laws, public interest and morality.

Regarding the supervision of regional regulations and regional head regulations born from the authority of central government supervision in the administration of regional governments within the framework of the Unitary Republic of Indonesia specialists in making regional regulations. But the Constitutional Court in the plenary session was open to the public precisely April 5, 2017, through its Decision Number 137 / PUU-XIII / 2015 stating Article 251 of Law 23 of 2014 concerning the Regional Government regarding the authority to cancel Regency / city regional regulations can no longer be canceled by the Minister Domestic or Governor.

Decision of the Constitutional Court declares a Phrase "District / City regional regulations and in the provisions of Article 251 paragraph (2) and (4) Regional / District regulation phrases and or Article 251 paragraph (3) and Regency / City Regional Government Phrases cannot accept decisions cancellation of regional regulations and Law Number 23 of 2014 concerning Regional Government is contrary to the 1945 Constitution of the Republic of Indonesia and does not have binding legal force.

The decision of the Constitutional Court is not yet unanimous, because it was colored by dissenting opinions from 4 (four) constitutions which refused to revoke the authority of the Minister of Home Affairs in canceling regional regulations. The argumentation related to regional autonomy is the responsibility of government administration which ends in the President. Then, to complement the Decisions Number 137 / PUU-XIII / 2015, the Constitutional Court through Decision Number 56 / PUUXIV / 2016 states that the Central Government no longer has the authority to cancel Provincial regulations.

The Constitutional Court's ruling does not necessarily resolve the issue related to government authority in regional law products, this is because the ruling only applies to 
provincial regulations and district / city regulations, while regional head regulations (governor regulations and regent / mayor regulations), governors and The Minister of Home Affairs is still authorized to cancel it. The Constitutional Court is of the opinion that in its consideration that:

"... because the regulation of the regional head is one type of legislation based on Article 8 paragraph (2) of Law Number 12 of 2011, but because it was formed by the regional head as the bestuur unit, the higher authority has cancel regional head regulations. Cancellation and mechanism for filing objections to the cancellation of regional head regulations in regional government law is part of the mechanism for submitting supervision from the president or minister and the governor as representatives of the central government to the regional government or in other words as a form of supervision, not testing legislation in Bestuur's scope is higher for the bestuur lower unit. "

The Village Law and the Local Government Act can be seen from the various implementing regulations, for example the provisions of Article 16 paragraph (1) of the Republic of Indonesia Ministerial Regulation No. $1 / 2014$ concerning the establishment of regional law products stating that local legal products are legal products in the form of regulations Perda or other names are available, regulations with regional heads, DPRD regulations, and in the form of decisions including, decisions of regional heads, decisions of DPRD, decisions of DPRD leaders, and decisions of honorary DPRD bodies. Where previously in article 2 No. 1 Permendagri No. 1/2014 affirmed that local legal products consist of only two, namely arrangements and stipulations. Then the two types of legal products are further elaborated in Article 3 of the regional regulations or other names, regional head regulations, and DPRD regulations.

The hierarchy of local government confirmed only at the level up to the district. On the other hand, the Unitary Republic of Indonesia recognizes and protects the characteristics and localities of the village.

Local authority issues a cancellation rules and regulations after the regional head of the Constitutional Court's decision was mainly associated with the Article 37 of Law Regent Village authority shall resolve dispute over election of heads of village. In addition to the Village Law attributed 24A paragraph (1) authorizes the Supreme Court to hear the appeal, examine the laws and regulations under the law against the law, and have other powers provided by law.

The activity mass media representative in the process of political campaign representation consist in serving as s channel for informingbthe audience. Potential voters, as the mean of election propaganda and as tool for civil control.

Based on the description above, the problems in this study are as follows; how is the authority to cancel regional regulations after the Constitutional Court Decision No. 137 / PUU-XIII /2015 and No. 56 / PUU-XIV /2016? 
Proceeding ICOGISS 2019

Page 778-794. ISBN: 978-602-6 988-75-1

Web Jurnal Online: jurnal.unmuhjember.ac.id

By: Fauziyah

Authority of Settlement of Village Head Election Post Constitutional Court Decision

\section{Model Supervision of the Regional Legal Products}

Article 18 paragraph (2) NRI 1945 Constitution states governments of the provinces, districts and municipalities to regulate and administer their own affairs according to the principle of autonomy and duty of assistance. Applicability of the principle of autonomy within Indonesia which divides authority between the central and regional affairs well is expected that any mandatory or optional can be carried out in accordance with the respective authority granted by Act No. 23/2014 on Regional Government.

In the study of constitutional law or administrative law known types of supervision. If viewed from the standpoint of the body or organ that carries out this authority over the object being tested, the testing system can be distinguished on: a) Legislative review (legislative review) if the testing authority is given to the legislative body b) Executive review if the authority tests it is given to the government, and c) Judicial review if the authority to test is given to the judicial agency.

Form of government's internal controls with two models of supervision, preventive surveillance a priori (executive preview) or repressive (monitoring a-posteriori (executive review).

Examination of the executive preview is intended to be a law that is applicable in the government environment before being legalized, it must first be examined and or approved by an official that is hierarchically higher in structural position than the agency that made the legislation. In this case the emphasis on preventive action is a test, because the aim is to maintain the utility (doelmatigheid) and validity (legality, rechmatigheid) of a law before it is validated and valid for the public. Furthermore, what is meant by executive review testing is intended a law that applies in the government environment after it is declared valid for the public but is re-examined and can be canceled by an institution that is hierarchically higher than the institution that made it. Then an aposteriori test is carried out after the regulation or decision is issued after the government action is taken. In this case the emphasis is on correcting and restoring wrong behavior made by the government or agency that issued the decision.

Form of executive review has the same properties as the administrative effort (internal review (English); bezwaarfase, (Netherlands). In short procedure administrative effort with various models for example Executiv preview or executive review aims, among others: 1) provide an opportunity for officials which issued a decision related to re-examine the legality and benefit from decisions or actions undertaken rejection; 2) provide an opportunity for the parties objected to use testing in non-litigation means that effective and efficient; c) extensive opportunities for the administration of Justice issued a decision to not burden the government. In accordance opinions Dacian C. Dragos and Bogdana Neamtu.

"... The formal objection procedure is not considered as a form of alternative resolution but as a preliminary stage of specific time limited court actions. It is a formal remedy verwaltungsakte againts the which is Generally Considered one to serve three objectives a) to give the issuing authority the opportunity to interally review the lagality and sustaability of the Verwaltungskakt or its rejections; b) To give the citizen an concered and efficient non-expensive non-judicial remedy; c) 
To releive adminitrative courts of claims that may be statified by the authority it self. "

So that the government can be run in accordance with the applicable legislation, the Government is authorized to conduct guidance and supervision of the regency /city. The authority is meant here in the form of checking whether a decision by the regional regulation and areas which have been made by the region contrary to the public interest or regulations vertically and horizontally. The local government autonomy act under the authority of the President.

Responsibility end in governance is in the hands of the President, then the consequences authority to cancel the regional regulation is in the hands of the President. It is not efficient then president cancellation delegate authority to the Minister provincial regulations as pembatu President responsible for the implementation of regional autonomy. Regulation cancellation of districts /cities, President mendelegasikankepada governor presides at the center of the area. That is the rules and regulations provincial governor as opposed to the general provision, contrary to the legislation both vertically and horizontally, or decency then canceled by the Minister. Similarly, the regulations of the district /city and regulation regents then canceled by the governor as a representative of the center.

Provincial government may appeal the cancellation of Provincial Laws revoked by the minister to the president, to avoid arbitrariness. Furthermore, local government district / city can appeal to the governor.

In the administration of local government, decisions made by the president and minister are final. If the provincial or regency / city government administrators still impose regional regulations that are canceled by the minister or governor as representatives of the central government, then the regional government is sanctioned.

\section{Norms Level Theory}

Kelsen argued that in the establishment of legislation known as legal level theory (stufentheori). In the theory of Kelsen found berjenjang- legal norms level and layered in a hirearkhi (governance arrangement) in the sense of a norm of higher force, sourced and based on the norms still higher, and so on. Up to a norm that can not be pursued further and that is a hypothetical and fictitious basic norms (grundnorm). "The Ground norm is not constitution, it is simply the supply, demand by theory, that this constitution ought to be obeyed."

Basic norms are the highest norms in a system of norms that are no longer formed by a higher norm, but the basic norms are determined in advance by the community as a basic norm which is a hanger for the norms under it, so that a basic norm said to be preexpected.

According to Kelsen a legal norm that always sourced and based on the norms on it, but under the legal norms it has also become the source and the basis for a lower norm thereof. In terms of governance arrangement / hierarchical system of norms, the highest norm (norm base) it becomes the dependent norms below, so if the basic norms of the change would be corrupted system of norms that exist underneath. 
Proceeding ICOGISS 2019

Page 778-794. ISBN: 978-602-6 988-75-1

Web Jurnal Online: jurnal.unmuhjember.ac.id

By: Fauziyah

Authority of Settlement of Village Head Election Post Constitutional Court Decision

Nawiasky developed Kelsen's theory of the level of norms in relation to the legal norms of a country which states that a legal norm of any country is always layered and tiered. The norms below are valid, are sourced and based on higher norms, higher norms apply, are sourced and are based on the highest norms called basic norms. As a student of Kelsen, the theory developed by Nawiasky in addition to the norm is layered and tiered, the legal norms of a country are also grouped, and the grouping of legal norms in a country consists of four major groups, among others.

a. Staatsfundamentalnorm ;

b. Staatsgrundgesetz;

c. Formell Gesetz;

d. Verordnung \& Autonome satzung

According Nawiasky, staatsfundamentalnorm contents are norms that are the basis for the establishment of a constitution or basic law of a country (staatsverfassung), including amendments norm. Itself a staats- fundamentalnorm law is a requirement for the enactment of a constitution or basic law. It exists before the constitution or constitution. Furthermore, Nawiasky said that the highest norms that Kelsen called the basic norms in a country should not be referred to as norms of norms, but fundamental principles or fundamental norms of the state. Grundnorm has a tendency to remain unchanged or permanent, while within a country the fundamental norms of the country can change at any time due to rebellions, coups, and so on. Verordnung \& Autonome satzung.

Indonesia as a legal state that adheres to the constitutional state of teachings like other modern countries, has a written constitution called the 1945 Constitution of the Republic of Indonesia. The 1945 NRI Constitution is placed as a fundamental law so that it becomes the basic law or source for making other laws and as a higher law Constitution NRI 1945 is the highest law in the order of the laws of the Republic of Indonesia. Contextually in a hierarchical system of legislation known as the three fundamental principles. The three principles referred to include the lex superior de rogat lex inferior principle, the lex specialist derogat lex generalis, lex posterior de rogat lex priori.

Based on the three principles of legal studies referred to is an important pillar in understanding the legal construction legislation in Indonesia in detail can be explained that:

a. Lex superior de rogat lex inferior principle, higher rules will override lower rules if governing the same and contradictory substances.

b. Lex specialist derogat lex generalis, more specific regulations will rule out general rules when regulating the same and conflicting substances.

c. Lex posterior de rogat lex priori, the new rules will override the old rules.

Thus, in each formulation of legislation must pay attention to the system of hierarchy of laws and regulations, so as to create harmony between the laws and regulations that are formed with various laws and regulations that are higher or equal. In this case, the 1945 Constitution of the Republic of Indonesia was used as a basic law in the legislation.

Constitution NRI 1945 as the legal basis of the legislation governing the regional authority to manage and administer their own affairs, in Article 18 paragraph (2) 
Constitution NRI in 1945 stated that the administration of the provinces, districts and municipalities to regulate and administer their own affairs according to the principle of autonomy and duty of assistance. Furthermore, Article 18 paragraph (6) confirms the regional government the right to set regional regulations and other regulations to implement autonomy and duty of assistance.

The implementation of the principle of autonomy within the Indonesian state which divides authority between the center and the regions is expected that all matters, whether compulsory or optional, can be carried out in accordance with the respective authorities granted by Law No. 23/2014 concerning Regional Government. Regional authority in the implementation of this autonomy has been implied by Law No. 23/2014 concerning Regional Government in the general explanation stated that the area as a legal community unit that has autonomy, has the authority to regulate and manage the area according to the aspirations and interests of the community insofar as it does not conflict with the order national law and public interest.

\section{The Idea and The Development of The Election Village Heads}

The original manuscript was not familiar with the 1945 General election term (Election). After the third amendment to the 1945 Constitution then affirmed in Chapter VII of the Election, Article 22E paragraph 2 states: "The election was held to elect members of the House of Representatives, Regional Representatives Council, the President and the Vice President and the Regional Representatives Council". In the provisions of Article 22E number 2 of the 1945 Constitution, it is clear that Pilkada and Pilkades are not included as part of the election. In its development, the Law No. 22/2007 (now Law No. 15/2011 concerning General Election Organizers, Pilkada is considered as part of the election regime. Then there are provisions of Article 1 paragraph (2), (3) and (4) Law No 15/2011 only recognizing The General election legislative, Presidential Election and the election as part of the electoral regime, and soon there was a change after the issuance of the Constitutional Court Decision No. 97 / PUU-XI / 2013 which stated that the election was not an election regime but was part of the regional government regime. Beginning in 2015, there was a rapid dynamics of legislation in the field of holding elections. The shift in the authority of the judiciary is intense. Pursuant to Law No.1/2015, it is determined that the settlement of disputes over votes resulting from the election of regional heads is handled in stages by the High Court and the Supreme Court, as before before the Constitutional Court was formed, but later changed with the Law No. $8 / 2015$, then the issue of disputes over the results of the regional head election is returned to the Constitutional Court Constitutional Court Decision No. 97 / PUU-XI / 2013 which states that the election of regional heads is not part of the electoral regime but rather a regional government regime as referred to in Article 18 of the 1945 Constitution, bringing legal consequences to the Court not authorized to hear disputes over Regional Head Elections, which are followed up with authority restore the authority of the Supreme Court to adjudicate election disputes based on Law No. 1/ 2015. Ironically Law No. 8/ 2015 the authority of the Constitutional Court to hear disputes over the results of the election was revived until a special election court was formed. However, planing for special election courts does not seem to reach the problems that occurred in the 
Proceeding ICOGISS 2019

Page 778-794. ISBN: 978-602-6 988-75-1

Web Jurnal Online: jurnal.unmuhjember.ac.id

By: Fauziyah

Authority of Settlement of Village Head Election Post Constitutional Court Decision

implementation of the election results. This condition is the ambiguity of the election of the village head including part of the electoral regime or the regional government regime or a special regime of village government.

Village elections are considered as part of the general election regime, the State Administration of justice, let alone the general Court has no authority to adjudicate disputes village elections. However, to meet the regime's contention that the village chief election into the regime of the general election, of course, the organizers Selection village head should be the domain of the District Election Commission and not by the Agency for Rural representation and the election committee as practiced now. Because that is the exception to the object of the State Administration dispute based on Article 2 number 7.

In the Village Law only regulates the disputes over the results of the election of the village head that is completed no later than 30 (thirty) days by the regent since the submission of the results of the election from the election committee of the village head in the form of a regent's decision. It can be interpreted that the Village Law has not regulated how disputes originating from the process of organizing the election of the village head, if examined, tried and decided by the court. Government Regulation Number 43/2014 concerning the implementing regulations of Law Number 6/2014 concerning Villages, also does not regulate the mechanism for resolving disputes. The selection of village heads concerning the process and results. In line with the Minister of Home Affairs Regulation No. 112/2014 efforts to resolve disputes The selection of village heads is divided into two related processes and results. But in practice the dispute on the selection of village heads often occurs in terms of vote counting. The vote results determine the determination of candidates elected as village heads. From this perspective it is clear that the dispute over the election of the village head is a dispute caused by a vote miscalculation, vote inflation or manipulation as well as other matters affecting the results of the vote count, as well as general election disputes.

Based on the Minister of Home Affairs Regulation No. 112/2014 the Village Head Election dispute concerning the electoral process is resolved independently by the election committee, and the nature of the election committee's decision is 'final and binding'. Whereas for the Village Head Election dispute concerning the vote count, the regent is completed within 30 (thirty) days after the proposal for approval is received by the regent. To explain which disputes concerning the process and results can be seen the stages of the implementation of the Village Head Election itself. The selection of village heads is carried out through.

1. Preparation;

2. Nomination;

3. Voting;

4. Determination.

Of the four stages, the implementation of village head elections can be categorized into two major parts, namely the process and outcome stages.

The process stage involves meeting the requirements of the (administrative) village head candidates. Election committees like the Regional Election Commission in the type of election are authorized to conduct research on the requirements of prospective candidates including research on the completeness and validity of the nominating 
Proceeding ICOGISS 2019

Page 778-794. ISBN: 978-602-6 988-75-1

Web Jurnal Online: jurnal.unmuhjember.ac.id

By: Fauziyah

Authority of Settlement of Village Head Election Post Constitutional Court Decision

administration. In the Minister of Home Affairs Regulation No. 112/2014, the provisions of the process selection of village heads have not accommodated the means of the objection community (constituent candidates), for example, are not included in the voter list, whereas experience shows that inaccurate voter data often occurs as a source of dispute problems. must provide a means for parties who feel aggrieved during the preparation process The selection of village heads Including the problems of registered voters is possible based on the local Village Identity Card.

Herefore the problem of the process of selecting the village head in this ministerial regulation is focused on the issue of the requirements and completeness of the village head candidate. In this stage, the election committee checks the completeness and validity of the administration of the candidates for the village head in this process the election committee must get clarification from the competent authority which is equipped with a certificate from the competent. Then the results of the research announced by the election committee to the community as referred to in paragraph (3) must be processed and followed up by the election committee.

In the Minister of Home Affairs Regulation No. 112/2014, it is affirmed that the determination of village head candidates announced publicly by the election committee is final and binding. Based on the Minister of Home Affairs Regulation 112/2014 if there are parties who feel dissatisfied or object to the determination of certain results, then the person concerned can use the objection facility against the determination of candidates by the village head of the election committee before being announced by the election committee based on Article 26 paragraph (4) and (5) Minister of Home Affairs Regulation No. 112/2014. After the objection was addressed by the election committee and then announced, the announcement of the final and binding stipulation could not be questioned according to the legal logic of the Minister of Home Affairs regulation No. $112 / 2014$.

The problem then is in the phrase "final and binding" in Article 26 paragraph (4) and (5) Minister of Home Affairs regulation No.112/2014 cannot be contested, including to the State Administrative Court? The decision of the committee, although declared to be final and binding, does not mean that it cannot be questioned again in the State Administrative Court. What is meant by the definition of "final and binding" here is more directed as the end result of internal settlement. Thus the final and binding meaning is not interpreted as an administrative effort, therefore the provisions governing the implementation of village head elections, there is no one passport that regulates the mechanism of administrative efforts, so that the final and binding meaning cannot be linked to administrative efforts. The announcement of the determination by the election committee is still open to be sued in court in casu peratun. For the reason that the determination of the election committee which is "final and binding" is different in meaning from a court decision that has permanent legal force. (inkracht van gewijsde).

It must be acknowledged that some provisions of the legislation contain norms that state final and binding decisions, it can be said that in practice the meaning of the norm does not necessarily mean mutatis mutandis. For example the decision to impose disciplinary sentences by the Regional Police against members of the Republic of Indonesia Police who violate the code of ethics and discipline is stated that the relevant 
Page 778-794. ISBN: 978-602-6 988-75-1

Web Jurnal Online: jurnal.unmuhjember.ac.id

By: Fauziyah

Authority of Settlement of Village Head Election Post Constitutional Court Decision

laws and regulations are final but that does not mean that the decision of the Regional Police becomes unable to be tested by the court, even though the court verdicts often cancel decision of the regional police.

Related disputes concerning the village election voting results derived from the stages of voting and determination. The village head election committee determines the candidate for the elected village head based on the most votes. The elected village head candidate is then given his name by the election committee to the Village Consultative Body to be forwarded by the Village Consultative Body at the latest 7 (seven) days after receiving the report from the election committee to the regent. The report of the election committee is forwarded by the Village Consultative Body and then ratified by the regent no later than 30 (thirty) days from the date of receipt of the results of the election of the village head in the form of a regent's decision. If there is a dispute at the latest 30 (thirty) days from the date of receipt of the submission of the results of the election of the village head in the form of a regent's decision.

Then candidates elected village heads appointed by the regents or not later than 30 (thirty) days after the issue decision regent. This provision is slightly different from previous provisions that regulate the transmission of results by the elections and the election committee to the Village Consultative Body as forwarded by the Village Consultative Body to the regent through camat. If there are those who are not satisfied with the results of the elections and the settlement of disputes by the regents referred to the provisions of Article 37 of Law Number 6/2014 of Article 41 paragraph (7) PP. No. 43/2014 concerning the implementation of Law Number 6 of 2014 concerning Villages. Can you file a lawsuit in the State Administrative Court? This is related not mention the dispute settlement provisions of Article 26 paragraph (4) and (5) of Law Number. 6/2014.

The problem then the regent's authority in resolving the dispute over the village head is in the scope of government administration or semi-adjudication? If the interpretation of the settlement of electoral disputes ends and ends to the regent so that the court cannot question it again. Thus, there has been a "restraint" by the laws and regulations under the law in casu the minister of the interior regulation restricts access to "justice seekers" to obtain legal protection from the courts access to justice is part of human rights that cannot be restricted by laws and regulations under the law. The provisions of ministerial-level legislation should not limit access to justice seekers who feel aggrieved regarding the implementation of village head elections. 
Page 778-794. ISBN: 978-602-6 988-75-1

Web Jurnal Online: jurnal.unmuhjember.ac.id

By: Fauziyah

Authority of Settlement of Village Head Election Post Constitutional Court Decision

\section{Rules for the Election of Village Heads in Regional Regulations Vs Decision of the Constitutional Court Number 56 / PUU-XIV / 2016}

During the enactment of Law 32/2004, district / city governments have obligations regulating the conduct of village elections through local regulations. The character of regional autonomy which shows regional diversity is 'clearly visible' in Article 203 of Law 32/2004 implemented by local governments. Uniquely, such provisions are not found in Law 6/2014. The delegation of village head election arrangements to district governments as outlined in the form of regional regulations only concerns the determination of policies for the implementation of village head elections simultaneously (vide Article 31 (2) of Law 6/2014), whereas in Article 37 paragraph (6) of Law 6/2014 only contains norms requiring regents / mayors to settle disputes over the election of village heads, without any guidance whether regulated in a Regional Regulation or Regent Regulations. Furthermore, in Article 49 paragraph (1) of the Regulation of the Minister of Home Affairs 112/2014 only determines "... the simultaneous implementation of village head elections is regulated by regional regulations ....".

Based on the description above, it would be natural if the regulation of the election of village heads in each region could be different depending on the aspirations of the people absorbed by the legislative members in the preparation of Regional Regulations.

\section{Cirebon Regency}

Provisions on the settlement of disputes over the results of the election of the Village head are regulated in Paragraph 14 concerning disputes over the Kuwu Article 39 Election Results. 2 of 2015 concerning Village Government and Village Consultative Body which states: '... "(1) objections to the determination of election results can only be submitted by Kuwu candidates to the Regent no later than 3 (three) days after the determination of the election results.

(2) objections as referred to in paragraph (1) only relate to the results of vote counting that affect the election of candidates.

(3) In the event of a dispute over the results of the Kuwu election, as referred to in paragraph (2), the Regent shall resolve the said dispute no later than 30 (thirty) days from the date of receipt of the objection report on the Kuwu Election result.

(4) The Regent decides the dispute over the results of vote counting as referred to in paragraph (2) by taking into account the considerations of the Kuwu Election facilitation team and the Supervisory Team ... ". 
Page 778-794. ISBN: 978-602-6 988-75-1

Web Jurnal Online: jurnal.unmuhjember.ac.id

By: Fauziyah

Authority of Settlement of Village Head Election Post Constitutional Court Decision

\section{Sleman Regency}

Provisions for resolving disputes over the results of village heads are regulated in paragraph 2 concerning the objection of the results of Article 48 and 49 of the Regional Regulation of Sleman Regency. 5 of 2015 concerning the procedure for the selection and dismissal of the village head which reads as follows:

Article 48 (1) objection to the determination The results of the election of the head of the Village can only be submitted by the Candidate of the village head to the Regent within no later than 3 (three) working days after the determination of the election results.

(2) objections as referred to in paragraph (1) only relate to the results of vote counting affecting the election of candidates for village heads.

(3) The Regent resolves the dispute over the results of vote counting as referred to in paragraph (1) and paragraph (2) within a period of no later than 30 (thirty) working days as referred to in Article 47 paragraph (5).

(4) the settlement of disputes as referred to in paragraph (3) considers the input from the village level election committee of the BPD, the sub-district head and the regional level election committee.

(5) The decision of the Regent as referred to in paragraph (3) is final and binding.

Article 49 states that after the settlement of the dispute within the period referred to in Article 48 paragraph (3) there is still an objection to the determination of the elected candidate for village head, then the inauguration of the elected village head candidate will continue ... ".

\section{Bangka Regency}

Provisions on the resolution of disputes over the election of the village head are regulated in paragraph 2 concerning the objection of the results of vote counting Article 44 of Bangka Regency Regional Regulation Number 11 of 2015 concerning Guidelines for Nomination, Election, Appointment, Inauguration and Dismissal of village heads which read as follows:

".... In the event of a dispute over the results of the election of the village head, the Regent is obliged to settle the dispute within 30 (thirty) days after the complaint is filed by the candidate of the village head.

(2) Settlement of disputes as referred to in paragraph (1) is delegated to the regional election committee.

(3) the regional election committee as referred to in paragraph (2) follows up by conducting deliberations to resolve the dispute over the election of the village head whose results are set forth in the minutes of dispute resolution.

(4) Minutes of dispute resolution as referred to in paragraph (3) shall be submitted by the candidate of the village head of the complainant and reported to the Regent by being forwarded to the local BPD.

(5) Candidates for village heads who cannot receive the settlement given by the regent, can take legal procedures in accordance with the provisions of the prevailing laws and regulations.

(6) Submission of complaints as referred to in paragraph (1) does not delay the process of inaugurating the elected village head candidate ... ". 
Page 778-794. ISBN: 978-602-6 988-75-1

Web Jurnal Online: jurnal.unmuhjember.ac.id

By: Fauziyah

Authority of Settlement of Village Head Election Post Constitutional Court Decision

\section{Barito Regency}

Provisions on the settlement of disputes over the results of the election of the village head are stipulated in Article 50 paragraph (4) to paragraph (10) of the Barito Kuala District Regional Regulation Number 1 of 2015 concerning Procedures for Nomination, Election of Appointment, Inauguration and Dismissal of village heads which read as follows:

(4) objections to the results of the election can only be submitted by candidates for the village head within 7 (seven) days after the determination of the elected village head candidate to the election committee;

(5) The election committee of the village head together with the sub-district supervisory committee decides the objection to the results of the election as referred to in paragraph (4) no later than 3 (three) days after the objection is submitted by the prospective village head who objects;

(6) In the event that there is a complaint of objection to the results of the election by the candidate of the village head to the election committee, the election committee shall convey to the BPD concerning the objection;

(7) the objection as referred to in paragraph (4) only relates to the results of the vote count affecting the election of candidates for village heads.

(8) A lawsuit against the outcome of an election can be submitted by a candidate for the village head to the District Court within 3 (three) days after the election committee's decision is issued regarding the objection of the candidate of the village head;

(9) The District Court decides the Claim against the results of the election as referred to in paragraph (8) no later than 14 (fourteen) days after the claim has been registered by the candidate of the relevant village head;

(10) The decision of the District Court as referred to in paragraph (9) is final and binding ...".

\section{Pangandaran Regency}

Provisions on the settlement of the results of the election of the village head are stipulated in Article 56 paragraph (4) up to (10) Pengandaaran Regency Regional Regulation Number 11 of 2015, concerning the Procedures for Nominating, Election, Appointment, Inauguration and Dismissal of the Village Chief which reads as follows:

(4) objections to the results of the election can only be submitted by candidates for the village head within 7 (seven) days after the appointment of the elected village head candidate to the election committee:

(5) The Election Committee of the village head together with the sub-district supervisory committee decides the objection to the results of the election as referred to in paragraph

(4) no later than 3 (three) days after the objection is submitted by the candidate of the village head who objects;

(6) In case of filing an objection to the results of the election by the candidate of the village head to the election committee, then submitted to the BPD regarding the objection; 
(7) Objection as referred to in paragraph (4) only relates to the results of vote counting affecting the election of candidates for village heads;

(8) A lawsuit against the outcome of an election can be submitted by a candidate for the village head to the District Court within no later than 3 (three) days after the election committee's decision is issued regarding the objection of the candidate of the village head;

(9) The District Court decides the lawsuit against the results of the election as referred to in paragraph (8) no later than 14 (fourteen) days after the lawsuit has been registered by the relevant village head candidate;

(10) The decision of the District Court as referred to in paragraph (9) is final and binding ...".

Regional regulations of Cirebon, Sleman, Bangka, Barito and Pangandaran Regencies regulate the nature of the outcome of the settlement of the dispute resolution body, whether it is first and final, and binding, or can be compared and even prosecuted. If the outcome of the settlement of the dispute resolution body is first and final, the village head process can be held in accordance with the procedures and stages that have been set. But if the outcome of the settlement of the dispute resolution body can be compared and even adjudicated, the village head process can be significantly disrupted. Instead of resolving disputes, the dispute resolution body can be prosecuted.

The absence of an output arrangement from the settlement of village head disputes by the dispute resolution body can have broad legal implications. First and foremost is the emergence of a lawsuit over the validity of the village head after being determined definitively by the regent, both by the same complainant and other parties, both on the same and new disputes, even though the previous dispute was resolved by consensus by the settlement body dispute (election committee). Because of whatever and however the regent must ratify the village head no later than 30 (thirty) days after the election results are received from the Pilkades committee, there is or no dispute (Article 37 paragraphs (5) and (6) of Law 6/2014). Secondly, the definitive village head becomes uneasy in carrying out the tasks of the village administration because he is free from the possibility of legal claims for his appointment.

Legal implications for granting "authority" to the regent, namely (1). to make legal norms, and (2). to choose the way to resolve the Pilkades dispute, it is easier to understand if the Perda in Cirebon, Sleman, Bangka, Barito and Pangandaran are presented in the following table: 
Page 778-794. ISBN: 978-602-6 988-75-1

Web Jurnal Online: jurnal.unmuhjember.ac.id

By: Fauziyah

Authority of Settlement of Village Head Election Post Constitutional Court Decision

Comparison Of Substance, Procedures And Outputs

Setting The Settlement Of Village Choice Disputes

In Cirebon, Sleman, Bangka, Barito And Pangandaran District

\begin{tabular}{|c|c|c|c|c|c|c|c|}
\hline \multirow[t]{2}{*}{ Regional } & \multirow{2}{*}{$\begin{array}{l}\text { Principal } \\
\text { Disputes }\end{array}$} & \multirow{2}{*}{$\begin{array}{c}\text { Legal } \\
\text { Standing }\end{array}$} & \multirow{2}{*}{$\begin{array}{c}\text { Legal } \\
\text { Officer }\end{array}$} & \multirow{2}{*}{$\begin{array}{c}\text { Legal } \\
\text { Mechanisme }\end{array}$} & \multicolumn{2}{|c|}{ Legal decicion } & \multirow{2}{*}{$\begin{array}{l}\text { Legal } \\
\text { Basic }\end{array}$} \\
\hline & & & & & Succesful & Failed & \\
\hline Cirebon & - & $\begin{array}{c}\text { Village } \\
\text { Chief } \\
\text { Candidate }\end{array}$ & $\begin{array}{l}\text { Village } \\
\text { Head } \\
\text { election } \\
\text { committee } \\
\text { and District } \\
\text { supervisor. }\end{array}$ & Non Litigation & - & - & $\begin{array}{l}\text { Local } \\
\text { regulations }\end{array}$ \\
\hline Sleman & - & $\begin{array}{c}\text { Village } \\
\text { Chief } \\
\text { Candidate }\end{array}$ & $\begin{array}{l}\text { Village } \\
\text { Head } \\
\text { election } \\
\text { committee } \\
\text { and District } \\
\text { supervisor. }\end{array}$ & $\begin{array}{c}\text { Non Non } \\
\text { Litigation } \\
\text { Litigasi }\end{array}$ & - & - & $\begin{array}{l}\text { Local } \\
\text { regulations }\end{array}$ \\
\hline Bangka & - & $\begin{array}{c}\text { Village } \\
\text { Chief } \\
\text { Candidate }\end{array}$ & $\begin{array}{l}\text { Village } \\
\text { Head } \\
\text { election } \\
\text { committee } \\
\text { and District } \\
\text { supervisor. }\end{array}$ & Non Litigation & - & - & $\begin{array}{l}\text { Local } \\
\text { regulations }\end{array}$ \\
\hline Barito & - & $\begin{array}{c}\text { Village } \\
\text { Chief } \\
\text { Candidate }\end{array}$ & $\begin{array}{l}\text { Village } \\
\text { Head } \\
\text { election } \\
\text { committee } \\
\text { and District } \\
\text { supervisor. }\end{array}$ & Litigation & - & - & $\begin{array}{l}\text { Local } \\
\text { regulations }\end{array}$ \\
\hline $\begin{array}{l}\text { Panganda } \\
\text { ran }\end{array}$ & - & $\begin{array}{c}\text { Village } \\
\text { Chief } \\
\text { Candidate }\end{array}$ & $\begin{array}{l}\text { Village } \\
\text { Head } \\
\text { election } \\
\text { committee } \\
\text { and District } \\
\text { supervisor. }\end{array}$ & Litigation & - & - & $\begin{array}{l}\text { Local } \\
\text { regulations }\end{array}$ \\
\hline
\end{tabular}

Based on the content analysis of Local Regulation of Cirebon, Bangka, Sleman, Barito and Pangandaran above, dispute resolution village head elections, it can be a red thread that there is a "gap" legal dispute settlement arrangements Village Head Election. The question that arises is, how is the legal settlement of the dispute over the election of the Village Head above the Regional Regulation / Regent Regulations? Based on the 
Page 778-794. ISBN: 978-602-6 988-75-1

Web Jurnal Online: jurnal.unmuhjember.ac.id By: Fauziyah

Authority of Settlement of Village Head Election Post Constitutional Court Decision

theory of Hans Kelsen stufenbouw connected by Act No. 12/2011 Concerning the Establishment Regulation Legislation, the rule in question is Regulation Number 112 /2014. Having analyzed carefully, it turns Regulation No. 112 /2014 no legal norms Election dispute resolution Village. The next question then how is the legal settlement of the dispute over the Election of the Village Chief above the Minister of Home Affairs Regulation? With the same theory and law basis, the regulation referred to is PP 43/2014 concerning the Regulation of the Implementation of Law 6/2014 concerning Villages. After being analyzed carefully, PP 43/2014 also did not have legal norms for resolving disputes over Election of Village Heads.

\section{Conclusions}

From the description of the legal norms of the Electoral dispute resolution village head of the lowest rules in this Regulation to the Act, it can be concluded that is :

First, it is evident there is a legal vacuum Electoral dispute resolution village head, although the form of general norm though.

Secondly the dispute settlement arrangements Pilkades of the Regulation to the Act has been a real "sync", which is to delegate to the regent / mayor and regulated by the law.

Thirdly, therefore Local Regulations in the area of research, based on analysis and comparison-fill-fill, wide-ranging and very minimalist norms as should the legal norms to resolve a dispute, the legal norms which are often referred to as the procedural law.

Fourth, Related to Constitutional Court Decision No. 56 PUU / XIV / 2016 Minister of the Interior and the Governor no longer authorized to cancel the regulations of the district / city. With this ruling does not necessarily solve the problems of the constitutionality of the authority of the testing of local regulations that in fact hierarchically are under the law. This is because the Minister of Home Affairs can still cancel the Governor and Governor Regulation can cancel the regulation of regent / mayor. because the contents of the regulations in the research district has been synchronized with the Regulation on top of the disputed village elections remain to be resolved by the regents / mayors, and allow the parties (candidates for village heads) are not satisfied with the decision of the regents can be appealed in the District Court for a period of 3 up to 7 days. Thus, the Constitutional Court Decision No. 56 PUU / XIV / 2016 does not contradict the Law 6/2014 and the rules below. 
Proceeding ICOGISS 2019

Page 778-794. ISBN: 978-602-6 988-75-1

Web Jurnal Online: jurnal.unmuhjember.ac.id

By: Fauziyah

Authority of Settlement of Village Head Election Post Constitutional Court Decision

\section{Bibliography}

\section{Books}

C. Gragos dan Bogdana Neamtu (editors) Alternative Dispute Resolution in European Administrative Law, Springer, Verlag Berlin Heidelberg, 2014.

Dias, RWM, Jurisprudence, Fifth Edition, London :Butterworths, 1985.

Farida, M. Science legislation: type, function, and content material. Yogyakarta, Kanisius, 2010.

Hamidi, J. Et al Theory and Law of Regional Regulation Design. First Print, Malang, Brawijaya University, 2012.

Huda, Ni'matul, Problematic Cancellation of Regional Regulations, FH UII Press, 2014.

Jimly Assiddiqi, Constitutional Law, University of Indonesia Press, 2009.

Lewis, Clive B. Judicial Remidies in Public Law.2nd, Sweet \& Maxwell, London, 2000.

Manan, B. Some legal issues of Indonesian, Bandung, Alumni, 1993.

Sukardi, Dissertation of Cancellation of Regional Regulations in the Indonesian State Administration System, Airlangga University, 2009.

\section{Journals}

Lia Sartika Putri'Village Authorithy and Decision Rule Of The Village" Jurnal Legislasi Indonesia Vol. 13 No. 4 Desember, 2016.

Nurcholis Hanif, The Policy of The area of development of The Village, Jurnal Desentralisasi, Vol 11, No. 2, 2013.

Ramis R. Gazizof. Tatiana A. Nagovitsyna, Political Manipulation of the Media ( on the example of Mass Media of the Republic of Tatarstand) Astra Salvensis, Review Of History and Culture, year V, No. 10 January, 2017.

Sihombing, E. N. Development of Regulatory Authority Annulment of Local Regulations An Regional Head Regulations. Jurnal Yudisial Vol 10 No. 2 Agustus,2017.

Simanjutak, E. Judicial Review of Local Regulation and Village Regulation After the Amendment of Local Goverment law and Village Law. Jurnal Konstitusi Volume 13 No 3 September 2016. 